\title{
PEMBUATAN PIRANTI KEHIDUPAN MASYARAKAT DI MASA PANDEMI COVID-19
}

\author{
Achadyah Prabawati \\ Progam Studi Ilmu Administrasi Niaga \\ Sekolah Tinggi Ilmu Administrasi Pembangunan Jember \\ *Email: achadyahprabawati@gmail.com
}

\begin{abstract}
ABSTRAK
Desa Jatimulyo mempunyai masyarakat yang beraneka usia, pendidikan, pekerjaan, dan perekonomiannya. Sehingga perlu rencana dan informasi terlebuh dahulu untuk mengumpulkan dalam suatu kegiatan yang mengajak masyarakat untuk melakukan kegiatan yang positif. Adapun yang dimaksud dengan kegiatan yang positif adalah kegiatan yang tidak bertentangan dengan yang harus dilakukan. Hal ini digunakan untuk menghindarkan diri agar bebas dari penyakit yang lagi marak penyebarannya di dunia. Kegiatan preventif ini adalah mengajak masyarakat untuk belajar membuat Hand Sanitizer untuk bahan pembersihan tangan dari kotoran. Serta pembuatan Masker sebagai alat pelindung dari menghirup virus yang lagi beterbangan, sehingga masyarakat tidak tertular penyakit Covid-19. Dan juga pembuatan Connector sebagai bahan pengait penggunaan masker bagi mereka ibu-ibu dan remaja putri yang menggunakan hijab. Hand Sanitizer yang diperagakan adalah Hand Sanitizer yang sesuai dengan standar WHO. Sedangkan Masker yang diperagakan adalah masker untuk fashion yang juga sesuai dengan standar WHO dengan 3 lapisan. Kata kunci : Makser, Jatimulyo, Hand sanitizer
\end{abstract}




\section{Analisis Situasi}

Jatimulyo adalah desa yang mempuyai masyarakat dengan tingkat pendidikan Perguruan Tinggi sampai dengan yang belum pernah mengalami Pendidikan formal. Sedangkan usia masyarakat desa Jatimulya diawali yang masih baru lahir yaitu seorang bayi, berkembang menjadi anak dengan usia Paud, anak-anak usia sekolah dasar, remaja sekolah tingkat SLTP dan SLTA serta mereka yang mulai menginjak dewasa dengan Pendidikan Perguruan Tinggi. Hingga sampai dengan mereka para dewasa hingga manula yang sudah masuk dalam usia perkawinan hingga membentuk keluarga; beranak pinak hingga bercucu-cicit.

Semenjak diumumkan kasus Covid-19 pada bulan Maret 2020 oleh presiden Joko Widodo, pemerintah terus berupaya melakukan langkah-langkah inisiatif dengan penanganan seoptimal mungkin agar virus tidak semakin menyebar dan membawa banyak korban jiwa. Beragam pilihan kebijakan ditempuh untuk menghadang laju, mulai dari penerapan Physical Distancing hingga Pembatasan Sosial Berskala Besar (PSBB) di berbagai daerah yang terpetakan sebagai media penyebaran.

Terlepas dari berbagai kebijakan yang ditempuh, pemerintah Indonesia seperti pemerintah negara lain, yaitu belum dapat memprediksi secara akurat kapan pandemi ini akan berakhir. Salah satu harapan terbesar agar pandemi ini bisa ditanggulangi adalah penemuan vaksin yang diupayakan oleh berbagai ilmuwan dunia. Berdasarkan World Health Organization (WHO) temuan vaksin baru dapat terlaksana di akhir 2020 . Artinya seluruh masyarakat didunia harus membiasakan diri untuk hidup berdampingan dan berdamai dengan Covid-19. Masyarakat dihimbau untuk patuh mentaati dan menjalankan protokol kesehatan yang telah ditetapkan oleh pemerintah.

$$
\text { Perubahan perilaku }
$$
masyarakat untuk menjalankan aktivitas secara normal disebut dengan New Normal. New Normal dapat diartikan sebagai skenario 
untuk mempercepat penanganan Covid -19 dalam aspek kesehatan sosial ekonomi. Dibawah ini adalah gambar aneka penyebaran virus Corona.

Adapun prinsip utamanya adalah adaptasi kebiasaan baru dengan pola hidup yang akan menuntun pada terciptanya kehidupan dan perilaku baru masyarakat yang dikawal dengan penerapan protokol kesehatan secara ketat. Sehingga protokol kesehatan tersebut antara lain memastikan semua Pribadi Untuk Hidup Bersih dan Sehat (PHBS), adalah:

1. Menerapkan Physical Distancing pada semua aktivitas dengan jarak minimal satu meter antar pribadi.

2. Menghindari kerumunan

3. Mewajibkan semua pribadi menggunakan masker dalam bersosialisasi dan dalam perjalanan

4. Menyediakan Hand Sanitizer disetiap pintu masuk yang akan digunakan bagi semua pribadi yang akan memasuki ruangan/ lokasi

5. Selalu jaga kebersihan tangan dengan sabun dan air mengalir serta menggunakan Hand Sanitizer

6. Mengatur asupan nutrisi makanan yang didominasi dengan yang mengandung vitamin c

7. Pengecekan suhu badan untuk tidak melebihi 37,30 o Celcius

8. Selalu berolahraga

9. Ucap salam saat bertemu seseorang tanpa berjabat tangan

10. Hindari tangan menyentuh area wajah seperti mata, hidung dan mulut

11. Bersihkan handphone, kacamata dengan cairan desinfektan

12. Segera mandi dirumah setelah tiba dari perjalanan

Menurut Wiku Adisasmita Ketua Tim Pakar Gugus Percepatan Penanganan Covid-19, pemerintah mengumumkan rencana pengimplementasian kebijakan New 
Normal dengan mempertimbangkan analisis pada studi epidemiologis dan kesiapan masing-masing wilayah.

Berdasarkan data negara maka pertumbuhan kasus Covid-19 yaitu dengan penambahan sebanyak 3.963 orang pada 16/9/2020 yang berkembang penambahan menjadi 4.168 orang pada 19/9/2020 dan pada tanggal 20/9/2020 bertambah lagi sehingga sebanyak 244.676 orang dengan kasus konfirmasi positif yang terdiri dari 57.796 orang kasus aktif, 177.327 orang sembuh dan 9.553 orang meninggal dunia.

Dibulan oktober yaitu 20/10/2020 bertambah lagi sehingga sebanyak 3.602 orang dengan kasus konfirmasi positif yang terdiri dari 3.602 orang kasus aktif, 4.410 orang sembuh dan 117 orang meninggal dunia

\section{Landasan Teori}

Pandemi Virus Corona semakin luas. Masyarakat di seluruh dunia pun berlomba-lomba mencari cara agar tidak terjangkit Covid-19. Satu di antara cara gampang melakukan pencegahan terhadap penyebaran virus Corona adalah dengan menggunakan hand sanitizer.
Hand sanitizer mampu membersihkan dan mengurangi kuman yang ada di tangan. Namun, hand sanitizer atau cairan pembersih tangan ini sebaiknya hanya digunakan saat dalam kondisi terbatas, seperti saat kesulitan menemukan air bersih. Selain itu, perlu diingat, agar selalu membeli produk hand sanitizer di pasaran yang telah terdaftar di Badan Pengawasan Obat dan Makanan (BPOM).

Sebagai cara mengatasi kelangkaan hand sanitizer seiring tingginya permintaan, Organisasi Kesehatan Dunia (WHO) telah mempublikasi cara membuat hand sanitizer yang mudah dilakukan. Dilansir dari laman CDC, hand sanitizer harus mengandung setidaknya 60 persen alkohol untuk bekerja secara efektif. Ada dua formula yang diberikan oleh WHO, yakni menggunakan bahan gliserol dan etanol.

Bahan gliserol digunakan sebagai humektan (menjaga kelembaban) kulit. Kemudian dicampur dengan hidrogen peroksida yang mampu mengatasi bakteri yang 
terkontaminasi. Selain gliserol, WHO juga menyarankan penggunaan etanol.

Sebagai catatan, perlu diperhatikan cara membuat hand sanitizer, karena menggunakan bahan kimia. Mengacu pada proses pembuatan versi WHO, Anda harus menunggu sekitar 72 jam hingga hand sanitizer buatan sendiri itu siap dipakai.

Menurut WHO, cara membuat hand sanitizer versi Badan Kesehatan Dunia untuk mencegah penyebaran COVID-19 adalah sebagaimana berikut.

Pembuatan 10 liter Hand Sanitizer

Formula 1

1. Etanol 96 persen sekitar $8.333 \mathrm{ml}$

2. Hidrogen peroksida 3 persen sekitar $417 \mathrm{ml}$

3. Gliserol 98 persen sekitar 145 $\mathrm{ml}$

4. Air suling (distilasi) atau air matang yang sudah dingin

5. Formula 2

6. Isopopil alkhol 99,8 persen sekitar 7,515 ml

7. Hidrogen peroksida 3 persen sekitar $417 \mathrm{ml}$
8. Gliserol 98 persen sekitar 145 $\mathrm{ml}$

9. Air suling (distilasi) atau air matang yang sudah dingin

10. Alat-alat yang diperlukan

11. Gelas atau botol palstik berukuran 10 liter dengan sumbat ulir

12. Jerigen plastik berukuran 50 liter polythylene, yang tembus pandang untuk melihat tingkat cairannya

13. Tangki stainless steel dengan kapasitas 80-100 liter

14. Sodet kayu, plastik, atau logam untuk mengaduk adonan

15. Tabung pengukur

16. Gelas takar, corong plastik atau logam

17. Botol plastik dengan tutup anti bocor berukuran $100 \mathrm{ml}$

18. Botol kaca atau plastik berukuran $500 \mathrm{ml}$ dengan tutup sekrup

19. Alkohol meter, skala suhu di bagian bawah dan konsentrasi etanol

Cara membuat hand sanitizer sesuai standar dari WHO: 
1. Siapkan 10 botol kaca atau plastik berukuran 10 liter dengan tutup sekrup.

2. Pilih formula yang ingin dibuat sesuai takaran ke dalam jerigen.

3. Tambahkan hidrogen peroksida ke dalam jerigen.

4. Tambahkan gliserol ke dalam jerigen. Gliserol memiliki sifat yang kental dan lengket pada gelas ukur. Bersihkan gelas ukur dengan air distilasi atau air matang.

5. Tuangkan ke dalam jerigen sekitar 10 liter, dan tambahkan 1 liter air distilasi.

6. Aduk hingga tercampur rata.

7. Terakhir, segera bagi ke botol plastik berukuran 500 atau $100 \mathrm{ml}$. Simpan hingga 72 jam (3 hari) sebelum digunakan.

Hand sanitizer hanya sebagai alternatif pengganti jika sulit menemukan air dan sabun untuk membersihkan tangan. Penggunaan hand sanitizer dalam jangka panjang akan membuat kulit Anda mengalami gangguan kesehatan, seperti kulit kering dan sensitif. Hand sanitizer memiliki berbagai kandungan bahan kimia yang berisiko menyebabkan gangguan pada fungsi otot kerangka dan jantung manusia. Alkohol juga dipercaya mampu meningkatkan resisten bakteri. Maka dari itu, penggunaan hand sanitizer lebih baik digunakan ketika sulit mencari air dan sabun.

\section{Hand Sanitizer Gel}

Yang harus dipersiapkan adalah alkohol $99 \%$ atau isopropil sebanyak 0,75 cangkir, gel lidah buaya atau aloevera sebanyak 0,25 cangkir yang akan mambantu menjaga tangan tetap halus dan menangkal kerasnya alkohol, dan 10 tetes essential oil semacam minyak lavender atau menggunakan perasan lemon. Caranya adalah mencampur semua bahan kedalam botol dan campur menggunakan sendok panjang hingga menjadi gel.

Apabila membuat Hand Sanitizer spray maka bahan yang digunakan adalah mencampurkan tiga bahan antara lain yaitu $60 \mathrm{ml}$ alkohol 70\%, 70 gr Aloevera, 2 tetes 
essential oil. Cara penggunaan adalah dengan menyemprotkan ke bagian telapak tangan dan menggosok sekitar 30-60 detik untuk membunuh sebagian besar kuman.

\section{Masker Dan Connector Rajut}

Tehnik Dasar Merajut

Teknik dasar dalam merajut adalah bagaimana membuat bentuk rajutan dengan cara yang efisien.

1. Cara memegang benang

Pegang jarum hakpen di tangan kanan, kepala kait hakpen menghadap ke arah kita. Mulailah mengait benang dengan jarum di tangan kanan.

2. Macam-macam Teknik Dasar Merajut (crochet)

Teknik Rajut Pertama

Chain stitch $(\mathrm{ch})=$ tusuk rantai yaitu bentuk sebuah lingkaran dari benang, kaitkan jarum dan tarik benang melalui lubang tusukan (stitch

Slip stitch (sl st) = tusuk selip

yaitu tusukkan jarum di sela-sela lubang stitch, kait benang, lalu tarik melewati lubang stitch

Picot yaitu 3 rantai cluster adalah buat 3 tusuk rantai, tusukkan jarum di lubang stitch yang sama saat membuat rantai, kait benang, lalu keluarkan seperti membuat slip stitch (tusuk selip).

Single crochet (sc) yaitu tusuk tunggal caranya adalah buat ch (rantai), tusukkan jarum pada ch kedua dari jarum, kait benang keluar, kait benang, lalu tarik melalui lubang stitch sehingga tersisa 1 lubang stitch.

\section{Teknik Rajut Kedua}

1. $2 \mathrm{sc}$ decrease $(2 \mathrm{sc}$ dec) yaitu membuat 2 sc yang digabung menjadi satu stitch.

2. 2 sc increase (2sc inc) yaitu membuat 2sc dalam satu lubang stitch.

3. Half double crochet (hdc) yaitu membuat double crochet yang ditarik sekaligus

4. Double crochet (dc) yaitu membuat double crochet dengan menarik 2 kali setiap 2 lilitan benang

5. Teknik Rajut Ketiga

6. Treble (tr) yaitu Treble crochet dengan membuat 4 ch, mengait benang 2 kali, 
masuk lubang kait benang, sehingga ada 4 helai benang. Kait benang untuk keluar dari helai dengan berkurang satu persatu.

7. $2 \mathrm{dc}$ decrease $(2 \mathrm{dc}$ dec) yaitu membuat $2 \mathrm{dc}$ dari lubang berlainan yang ditarik sekaligus.

8. $2 \mathrm{dc}$ increase (2dc inc) yaitu membuat 2 dc dari satu lubang

9. $3 \mathrm{dc}$ cluster $(3 \mathrm{dc} \quad \mathrm{cl})$ yaitu membuat puff dengan membuat 3dcdari satulubang yang langsung ditarik sekaligus

\section{Teknik Rajut Keempat}

1. 3hdc cluster (3hdc cl) yaitu membuat 3hdc yang ditarik sekaligus dan ditutup dengan $1 \mathrm{ch}$

2. Pop double crochet (pop dc) yaitu membuat puff dengan $5 \mathrm{dc}$ dalam satu lubang yang ditarik sekaligus, dan ditutup dengan $1 \mathrm{ch}$.
3. Back post double crochet (bpdc) yaitu membuat double crochet dengan mengaitkan dengan lubang dibawah.

4. Front post double crochet (fpdc) yaitu membuat double crochet dengan mengaitkan dengan lubang dimuka

Mematikan Benang (Finishing)

1. Potong benang beberapa centimeter.

2. Kaitkan sisa benang tersebut.

3. Tarik sisa benang melalui lubang dengan bantuan jarum hakken

Mengenal Benang Rajutan

Benang rajut berbahan akrilik lembut (soft acrylic): Benang jenis ini sedikit lebih mahal dibandingkan benang rajut yang lain. Benang ini bagus untuk para pemula yang sedang belajar pola baru.

Benang rajut $100 \%$ katun (100\% cotton): Benang rajut katun bagus untuk membuat apa pun yang nantinya bisa sering dicuci karena 
benang jenis katun bersifat menyerap air dan mudah dicuci.

Benang rajut hias (novelty yarn): Benang rajut jenis ini memiliki variasi paling banyak. Benang dengan berbeda tekstur, warna, dll. Pada umumnya berharga paling mahal. Novelty yarn terbuat dari bahan wol yang sangat halus sehingga akan menghasilkan sweter ataupun selendang/syal (scarf) yang sangat nyaman dipakai . Benang rajut jenis ini tidak dapat dicuci sesering benang katun

Cara pegang hakpen

1. Posisi Over-the Hook: Pegang hakpen dengan gagang berada dalam genggaman, seperti halnya memegang pensil. Ibu jari harus berada di atas hakpen, sementara jari telunjuk dan jari yang tersisa menggenggamnya.

2. Posisi Under the Hook: Pegang hakpen seperti memegang spatula/kape atau pisau. Ibu jari harus berada di bawah hakpen, sementara jari telunjuk ditempatkan bersama jari yang tersisa

Cara menyambung benang dalam merajut
Untuk menyambung benang, dengan benang warna lain, agar rajutan lebih rapi dan sambungan warnanya tetap sesuai bentuk dan menghasilkan motif yang rapi, adalah:

1. Ambil benang baru saat akan mengakhiri suatu tarikan benang terakhir

2. Buat tusukan baru pada lubang stitch di sebelahnya dengan benang baru, kaitkan benang lalu tarik

3. Mulai membuat tusukan SC atau DC dengan benang yang baru

\subsection{Perumusan Masalah}

Masalah menurut Surachmad (1975:38) adalah merupakan kesulitan yang menggerakkan manusia untuk memecahkannya. Secara sederhana dapat dikatakan bahwa masalah merupakan tantangan yang harus dihadapi dan dicari jalan keluarnya, dengan berbagai alternatif pemecahan sehingga masalah itu dapat dipecahkan secara rasional dan berdasarkan metode ilmiah.

Pada umumnya setiap individu atau organisasi dalam mencapai tujuan pasti mengalami beberapa kesulitan 
yang saling berkaitan antara satu dengan yang lainnya. Sudah tentu kesulitan akan dapat diatasi dengan cara memecahkan masalah atau kesulitan itu sendiri. Untuk itu didalam menghadapi kesulitan, setiap individu atau organisasi harus mengidentifikasikan permasalahan kedalam beberapa bagian, sehingga memudahkan cara pemecahannya.

Permasalahan ini menurut Suharsini Arikunto dibedakan atas tiga jenis, yaitu masalah untuk :

1. Mengetahui status dan mendeskripsikan fenomena;

2. Membandingkan dua fenomena atau lebih (problem komparasi);

3. Mencari hubungan antara dua fenomena.

Berdasarkan pendapat Suharsini Arikunto tersebut yang dikomparasikan dengan latar belakang diatas maka ruang lingkup yang menjadi batasan kegiatan pengabdian masyarakat ini adalah untuk mendiskripsikan semua hal yang ada sangkut pautnya dengan proses peningkatan kualitas remaja. Remaja yang menjadi generasi penerus bangsa yang unggul, bertanggung jawab dan mandiri serta berjiwa potensial. Adapun permasalahan yang dapat diangkat adalah :

1) Bagaimana cara membuat Hand Sanitizer sesuai dengan petunjuk WHO?

2) Bagaimana cara membuat Masker?

3) Bagaimana cara membuat Connector?

Dengan menjawab semua permasalahan tersebut maka akan dapat membuat masyarakat segera dapat bertanggung jawab atas Kesehatan secara pribadi dan mandiri serta berjiwa potensial di desa Jatimulyo kecamatan Jenggawah Kabupaten Jember.

\section{Tujuan Kegiatan}

Pada dasarnya tujuan pengabdian masyarakat ini adalah memastikan semua Pribadi Untuk Hidup Bersih dan Sehat (PHBS), dengan mekonfirmasikan serta memberikan pelatihan dalam pembuatan Hand Sanitizer; Masker serta Connector terhadap Masyarakat 
di desa Jatimulya untuk memberikan kepemilikan tanggung jawab Kesehatan secara pribadi dan mandiri serta berjiwa potensial di Desa Jatimulyo Kecamatan Jenggawah Kabupaten Jember.

\section{Manfaat Kegiatan}

Program pengabdian pada masyarakat dilakukan di Masyarakat Desa Jatimulyo Kecamatan Jenggawah Kabupaten Jember mempunyai luaran yang diharapkan berupa :

1. Program silahturahmi ke masyarakat Desa Jatimulya

2. Pelatihan pembuatan Hand Sanitizer sesuai petunjuk WHO

3. Pelatihan pembuatan masker berbahan benang Poliesther

4. Pelatihan pembuatan connector berbahan benang Poliesther

Program pengabdian pada masyarakat yang dilakukan di Masyarakat Desa Jatimulya Kecamatan Jenggawah Kabupaten Jember mempunyai kegunaan yaitu mengawali proses pembentukan tanggung jawab Kesehatan pribadi secara mandiri serta berjiwa potensial dengan menanamkan dan memastikan semua Pribadi Untuk Hidup Bersih dan Sehat (PHBS).

1. Kerjasama Perti dengan dunia pendidikan masyarakat

2. Pelaksanaan pola sosialisasi kehidupan yang sehat

3. Membudayakan pola prilaku Perlindungan Kesehatan \& Kebersihan

4. Pemberian pelatihan pembuatan Hand Sanitizer sebagai bahan pembersih

5. Pemberian pelatihan pembuatan Masker \& Connector sebagai bahan pelindung tubuh dari bahaya virus penyebar penyakit

6. Peningkatan kualitas masyarakat yang unggul, bertanggung jawab atas Kesehatan pribadi dan mandiri serta berjiwa potensial 


\section{Kerangka Pemecahan Masalah}

Untuk dapatnya memastikan semua Pribadi Untuk Hidup Bersih dan Sehat (PHBS), maka pemecahan permasalahan yang dapat diangkat adalah memberikan pelatihan :

1) Membuat Hand Sanitizer sesuai dengan petunjuk WHO

2) Membuat Masker berbahan rajutan
3) Membuat Connector berbahan rajutan

\subsection{Khalayak Sasaran}

Wilayah desa Jatimulyo yang disebelah utara dibatasi oleh desa Sruni Kecamatan Jenggawah, serta disebelah selatan adalah desa Sidodadi/ Pontang Kecamatan Tempurejo. Sementara wilayah timur dibatasi oleh PTP12 Glantangan Kecamatan Tempurejo, dan sebelah barat adalah desa Jatisari kecamatan Jenggawah. Wilayah desa Jatimulyo dekat dengan jalan raya yang menghubungkan kota Jember dengan tempat wisata Watu Ulo, pantai Papuma, pantai Love dan pantai Payangan sehingga mudah untuk dijangkau. Selain itu dekat dengan pelelangan ikan Puger sehigga hal ini akan mengundang banyak konsumen para wisatawan.

Wilayah desa Jatimulyo seluas 3.900 Ha dihuni oleh penduduk sejumlah 6.342 jiwa dengan 1778 kepala keluarga. Sepertiga belas dari keluasan wilayah tersebut berupa lahan persawahan seluas $296 \mathrm{Ha}$ yang dimiliki oleh 894 petani. Sementara penduduk yang lain adalah bekerja sebagai pedagang dan pegawai negeri sipil masing-masing sejumlah 15 orang dan 228 orang wiraswasta. Sehingga sisanya sejumlah 5.190 orang adalah mereka penduduk yang harus dibiayai. Mereka adalah para balita, para murid paud dan TK, para siswa SD/ SMP/ SMA \& SMK serta mahasiswa, juga para manula.

Dari jumlah penduduk sebagaimana diatas maka setiap orang yang bekerja membiayai 3 sampai 4 orang anggota keluarga. Sementara dengan 296 Ha lahan persawahan yang dimiliki oleh 894 petani maka menunjukkan rata-rata kepemilikan sawah seluas sepertiga hektar. Bila hasil panen 12 ton per 
hektar sawah dengan hasil keuntungan pertanian dengan kisaran Rp 5.600.000,- setiap empat bulan. Maka pendapatan setiap petani adalah Rp 465.000,- per bulan. Hasil pertanian tersebut untuk membiayai 3 orang anggota keluarga atau 4 orang dengan dirinya. Artinya petani desa Jatimulyo yang merupakan separuh dari jumlah penduduk desa Jatimulyo termasuk ekonomi rendah karena setiap orang mempunyai dana konsumsi sebesar Rp3.865,- per hari. Sementara dari 15 pedagang dan 228 wiraswasta sehingga dengan kisaran 970 orang atau sekitar sepertujuh atau $14 \%$ dari penduduk desa Jatimulyo dapat dipastikan berada dalam tingkat perekonomian menengah. Karena para pedagang dan para wiraswasta pasti punya penghasilan perhari sekitar diatas Rp50.000,- yang akan dinikmati oleh 4 orang dalam keluarga. Artinya mereka mempunyai tingkat perekonomian lebih tinggi. Berbeda dengan para pegawai negeri sipil yang sejumlah 15 kepala keluarga tersebut yang mempunyai pendapatan minimal sesuai UMR yaitu Rp2.400.000,- per bulan.
Artinya anggota keluarga dari pegawai negeri sipil penduduk desa Jatimulyo termasuk ekonomi menengah karena setiap orang mempunyai konsumsi minimal sebesar Rp 20.000,- per hari.

Dengan bervariasinya kelompok penduduk maka dapat dipastikan bahwa tingkat komunikasi dan sosialisasi penduduk sangatlah padat. Sehingga perlu adanya program penjagaan dan pemantauan kesehatan penduduk.

\section{Metode Kegiatan}

Studi kelayakan mengenai piranti kehidupan masyarakat dimasa pandemi covid-19, antara lain yaitu mempunyai tahapan :

1. Program Silahturahmi Kedunia Piranti Kehidupan Masyarakat

Kerjasama Perguruan Tinggi STIA Pembangunan Jember terhadap dunia pendidikan Masyarakat di Desa Jatimulyo Kecamatan Jenggawah Kabupaten Jember. Pada kegiatan tersebut tercatat bahwa terdapat 12 orang ibu rumah tangga dan 8 orang kepala keluarga. 
Kegiatan masyarakat sangat berkaitan dengan klasikal social ekonominya. Masyarakat yang penuh dengan kebutuhan pribadi untuk diperhatikan dan untuk disegani. Mereka yang merasa terpenuhi tidak bermasalah, tetapi bagi mereka yang pendiam dan introvert maka tidak akan mendapatkan. Sehingga mengakibatkan perilaku yang beda. Mereka banyak termenung, berandaiandai, penuh harap dan akhirnya mereka tidak sadarkan diri. Selanjutnya yang mereka lakukan adalah tindakan lain-lain diluar kewajaran.

Perilaku diatas merupakan sisi negatif yang seharusnya tidak harus terjadi. Apabila mereka punya pola pikir yang positif dan wajar maka mereka akan menunjukkan potensi dirinya sehingga menarik perhatian teman bahkan masyarakat umum. Karena setiap manusia selalu memiliki kelebihan selain kekurangan pada dirinya.

2. Pola Hidup Sehat Dan Bersih Manusia lahir didunia langsung melakukan kegiatan yang disebut dengan belajar. Belajar bernafas dengan tangisan. Belajar proses pencernaan yang dipandu oleh ibu dengan minum air susu ibu hingga disuap makanan. Makanan yang diberikan pun bertahap mulai dari yang paling lunak hingga beraneka jenis makanan. Belajar bicara yang dipandu oleh orang tua bahkan siapa saja yang didekatnya dengan sapaan. Bahkan belajar bersosialisasi dengan mengharuskan menengok sipemanggil dan menjawab bila dipanggil. Belajar olah otak dengan mengajak bernyanyi dan berhitung.

Usia balita adalah waktu pertumbuhan fisik maupun psikis. Pada usia inilah mulai pembentukan corak kepribadian anak. Anak diajarkan untuk bicara dengan sopan santun serta tahu etika. Anak diajarkan untuk berperilaku sesuai tata krama dan sopan terhadap yang lebih tua. Anak diajarkan bersikap baik serta jujur dalam bertindak. Anak diajarkan ikhlas dan menerima apa adanya atas pemberian orang tua.

3. Penanaman Pola Pemikiran Yang Wajar

Setelah masa pendidikan formal maka anak diajarkan untuk berfikir secara wajar sesuai teoritika. Menyelesaikan soal sesuai dengan 
metode dan teori yang menjadi dasar pemikiran. Memberikan solusi apabila terjadi permasalahan serta memberikan kesimpulan sebagai dasar pedoman yang harus dilakukan bila terjadi permasalahan yang sama. Juga meminta saran pemikiran untuk mempersingkat penyelesaian dan pemberian solusi bila terjadi permasalahan.

Penyelesaian permasalahan bukan dengan adu bicara, adu tenaga, adu kekuatan raga. Masalah harus dibicarakan dengan tenang, dicari akar permasalahannya dan disusun solusinya. Bukan dilakukan dengan pertikaian dijalan raya pula. Hal ini sangat mengganggu keamanan warga setempat serta keamanan pengguna lalu lintas. Hal inilah maka sangat diperlukan adanya perilaku tata krama serta etika dan sopan santun bagi semua.

4. Bahan Hand Sanitizer Yang Disarankan Oleh WHO

Dengan kehidupan didunia maka terjadi daur siklus kehidupan. Dari nyamuk yang bertelur diair akan menetas menjadi jentik-jentik. Bila jentik-jentik sudah diam mengapung dipinggir bejana maka akan tumbuh sayap untuk terbang menjadi nyamuk. Dari kupu-kupu yang bertelur didaun akan menetas menjadi ulat. Ulat yang tua akan diam tumbuh selaput dan menjadi kepompong. Dan selanjutnya kepompong akan terobek dari dalam dan keluar kupu-kupu yang akan tumbuh dewasa. Katak bertelur diair dan menetas menjadi berudu. Berudu berenang yang bernafas dengan insang dan berenang dengan siripnya. Sirip tumbuh menjadi kaki dan siap untuk melompat menjadi kecebong. Kecebong melompat kedarat dan bernafas dengan paruparu menjadi katak. Akhirnya katak tumbuh dewasa. Semua itu siklus kehidupan binatang.

Berbeda dengan pertumbuhan manusia. Manusia lahir setelah pertumbuhan dalam rahim ibu selama sembilan bulan sepuluh hari. Tiga bulan pertama bayi manusia hanyabisa terlentang menyusu dan menangis. Usia empat bulan bayi baru belajar tengkurap, lima bulan baru dapat tengkurap dengan menyagga tubuh dengan tangannya serta terguling telentang lagi. Usia 
tujuh bulan baru belajar duduk, dan delapan bulan baru meraih untuk mengangkat badan dan berdiri dengan pegangan. Sembilan bulan baru belajar melangkah dengan pegangan. Sehingga usia setahun mulai belajar barjalan sendiri.

Manusia diusia balita hanya menerima pemberian orang tua. Diusia anak- anak mulai belajar mengambil yang disiapkan orang tua. Remaja adalah usia yang dipersiapkan untuk mandiri, belajar mengambil keputusan, dengan perubahan psikis serta hormon genetik yang semakin produktif. Kondisi ini yang merubah kondisi seseorang menjadi dewasa, dan siap untuk bereproduksi. Sebagai manusia yang agamis dan bermasyarakat maka untuk bereproduksi harus dilakukan secara hukum dengan pernikahan di Kantor Urusan Agama di Gereja atau di Kantor Catatan Sipil.

5. Pengenalan Perilaku Kehidupan Masyarakat Dengan Tanggung Jawab Kesehatan Pribadi dan mandiri serta Pola Hidup Bersih.
Remaja sebagai generasi penerus bangsa Indonesia harus dapat berkarya secara mandiri. Maksudnya adalah membuat hasil karya sesuai dengan kemampuan pribadi. Hasil karya yang dapat digunakan oleh orang banyak dan mempunyai nilai ekonomis. Kondisi ini akan memberikan pendapatan ekonomi bagi si pemrakarya.

Remaja harus bertanggung jawab atas perilaku yang telah diperbuat. Maksudnya agar hasil karya yang digunakan oleh masyarakat harus menghasilkan kegunaan yang positif. Bukan membuat masyarakat menjadi bermasalah.

Untuk itu maka remaja harus unggul yang berjiwa potensial. Sehingga remaja itu harus mempunyai sifat keunggulan budi pekerti agar tidak menjadikan Indonesia semakin terpuruk, melainkan semakin jaya. Hal inilah yang disebut dengan berjiwa potensial.

Kegiatan pengabdian pada masyarakat Desa Jatimulya Kecamatan Jengawah Kabupaten 
Jember mempunyai tiga tahapan dalam operasionalnya.

1. Tahap pertama adalah:

- mempersiapkan materi pengabdian

- melakukan pengurusan perijinan

- mempersiapan media dan kebutuhan administrasi

- mempersiapkan anggota peserta pengabdian

- mempersiapkan bahan untuk penggerak motivasi para audience.

2. Tahap kedua adalah pelaksanaan pengabdian masyarakat yang dibuka dengan sambutan pengenalan, pemaparan materi pengabdian masyarakat, diskusi permasalahan dan penyimpulan dan penutup. Adapun isi dari pemaparan materi pengabdian pada masyarakat anatara lain adalah :

3. Tahap ketiga adalah pelaporan

- Pengumpulan dokumentasi yang berupa surat perijinan yang sudah ditanda- tangani dan daftar hadir peserta pengabdianmasyarakat

- Penulisan laporan pengabdian pada masyarakat
- Pengadministrasian

pada lembaga perguruan tinggi.

\section{Evaluasi Kegiatan}

Dalam rangka kegiatan pengabdian pada masyarakat selalu diadakan sesi diskusi yang akan membahas point apa saja yang perlu diperdalam sehingga menambah pengetahuan masyarakat mengenai topik yang dibahas. Ada dua kegiatan dalam acara evaluasi kegiatan. Yang pertama adalah memberikan peluang terhadap audience untuk bertanya. Dalam hal ini ada dua pertanyaan yang sangat berarti sehingga perlu dikaji. Adapun pertanyaanny adalah :

Pertanyaan pertama yang dapat dihimpun adalah "Mengapa dalam membuat Hand Sanitizer lebih baik menyimpan selama 3 hari untuk penggunaannya?" pertanyaan ini dapat dipahami bahwa audience mengerti dan antusias dalam pembuatan Hand Sanitizer. Penyimpanan disini dimaksudkan agar pencampuran cairan kimia dapat sangat bersatu sehingga dapat dengan sempurna mengakibatkan 
hasil yang dikehendaki untuk pembersihan tangan.

Pertanyaan kedua adalah “ Mengapa dalam pembuatan Masker Rajut diperlukan dua lapis kain untuk furingnya. Sementara ada masker kain yang hanya satu lapis saja" Pertanyaan ini menandakan bahwa audience sangat jeli terhadap aneka jenis masker sebagai perangkat kehidupan membatasi diri dari menghirup virus corona. Sesuai dengan peraturan WHO bahwa masker seharusnya terdiri dari tiga lapis. Lapisan luar adalah untuk fashion. Lapisan tengah untuk fertilisasi dari udara yang dihirup. Lapisan dalam adalah lapisan bersih yang akan menempel pada wajah manusia sehingga bebas dari kotoran. Dan yang kedua adalah pemateri memberikan pertanyaan agar dijawab oleh audience. Sebenarnya ada tujuh pertanyaan yang sempat dilontarkan, antara lain adalah :

Pertanyaan pertama adalah “ Apa jenis masker yang disarankan oleh WHO? "Sebenarnya ada 5 jenis masker yang disarankan oleh WHO yakni masker PNG, masker Sensi, Masker N95, masker KN95 dan masker Duckbill. Tetapi dijawab oleh satu audience yaitu masker N95. Hal ini menunjukkan bahwa masyarakat desa Jati Mulyo sudah paham dengan materi yang telah diberikan.

$$
\text { Pertanyaan kedua yaitu “ Apa }
$$

fungsi aquadest murni dalam pencampuran Hand Sanitizer ? “ dalam pertanyaan ini beberapa audience saling menambahkan masing-masing jawabannya sehingga menunjukkan kebenaran. Yaitu sebagai media cairan. Ada juga yang menjawab agar tidak cepat menguap sehingga dapat dengan leluasa untuk mengeluarkan kotoran. Untuk melengkapi volume sehingga dapat menjadi 1 liter atau 10 liter Hand Sanitizer sehingga dengan mudah dapat dibagi untuk didistribusikan ke dalam botol spray dengan tidak bersisa.

\section{DAFTAR PUSTAKA}

Ashari Meisar. 2016. Kritik Seni. Makassar. Media Qita Fondation. 
Arikunto, Suharsimi. 1983. Prosedur

Penelitian Suatu Pendekatan

Praktek. Jakarta.PT. Rineka

Cipta.

Bachri, Syamsul. 2005. Psikologi

Perkembangan. Makassar.

Badan Penerbit Universitas

Negeri Makassar.

Bell, Gredler, Margare. 1991. Belajar dan Pembelajaran.Jakarta.PT Rajawali.

Dimyanti, Mujiyono. 2002. Belajar dan Pembelajaran. Jakarta.

Renika Cipta.

Faisal,Muhammad. 2015.

Antropologi Seni. Makassar:

Badan Penerbit Uneversitas

Muhammadiyah Makassar.

Ginting Regina, Ema. 2015.

Identifikasi Kesulitan Belajar

Mengait (Crochet) Pada Siswa

Kelas X Di SMK Karya Rini

Yogyakarta. Yogyakarta:

Universitas Negeri

Yogyakarta.(http://www.skripsi.

pendidikanteknikbogadanbusana .ac.id.,diakses 02 Agustus 2018).

Henni Bakrie. 2019. Bros Bunga

Rajut. Rangkaian Bros Bunga

Dari Rajutan. Taiara Aksa.

Surabaya
Novelia Ummu Nayfan. 2018. Buku Rajut 3D Sentuhan Baru Rajutan Menawan - Kriya Pustaka. Jakarta Pusat. ,

Rohendi Rohidi, tjetjep. 2016. Pendidikan Seni: Isudan Paradigma. Semarang. Cipta Prima Nusantara.

Rohendi Rohidi, tjetjep. 2011.

Metodelogi Penelitian Seni.

Semarang. Cipta Prima

Nusantara CV. Rusman. 2016.

Model-model

Pembelajaran:Mengembangkan

Profesionalisme Guru-Ed.2.-

cet.6.Jakarta.rajawali Pers,

Salam, Sofyan. 2007. Metode Penelitian. Hand Out pada Jurusan Seni Rupa FSD UNMS

Setyosari,

2010.MetodePenelitianPendidik

an dan Pengembangan. Jakarta:

Kencana.

http://arugurumiproduction.blogspot.

co.id/2013/02/pengertian-

merajut-danmerenda-

merajut.html(akses 28 Des 2017)

https://id.wikipedia.org/wiki/Merajut

(akses 28 Des 2020) 
https://ilhamanjir.wordpress.com/201

7/01/26/pengertian-crochet-

hasilrajutan/ (akses 28 Des

2020)

http://rajut-

milkan.blogspot.co.id/2014/01/p

engertian-merajut-

menurutberbagai.html (akses 28

Des 2020)

https://www.tribunnews.com/kesehat

an/2020/03/27/cara-buat-hand-

sanitizer-gel-dan-spray-sendiri-

di-rumah-berikut-ini-

panduannya.(Penulis: Suci

Bangun Dwi Setyaningsih

Editor: Muhammad Renald

Shiftanto) (akses 20 Des 2020) 